\title{
Factor V G1691A is associated with an increased risk of retinal vein occlusion: a meta-analysis
}

\author{
Yuanyuan Zou ${ }^{1}, X$ Zhang ${ }^{1}$, Jingyi Zhang ${ }^{1}$, Xiangning $\mathrm{Ji}^{1}$ and Yuqing Liu ${ }^{1}$ \\ ${ }^{1}$ The Second Department of Ophthalmology, Cangzhou Central Hospital, 061001, Cangzhou, PR China \\ Correspondence to: Yuanyuan Zou, email: zouyuanyuanbird@sina.com
}

Keywords: factor $V$, retinal vein occlusion, polymorphism, meta-analysis

Received: June 27, 2017

Accepted: August 17, 2017

Published: September 04, 2017

Copyright: Zou et al. This is an open-access article distributed under the terms of the Creative Commons Attribution License 3.0 (CC BY 3.0), which permits unrestricted use, distribution, and reproduction in any medium, provided the original author and source are credited.

\section{ABSTRACT}

We performed a meta-analysis to investigate the association between the Factor V G1691A polymorphism and the risk of retinal vein occlusion (RVO). This analysis included 37 studies involving 2,510 cases and 3,466 controls. Factor V G1691A was associated with an increased risk of RVO in the allele, heterozygote, dominant, and carrier models ( $P A<\mathbf{0 . 0 0 1}$, odds ratios $>1$ ), but not the homozygote or recessive models ( $P A>0.05)$. Similar results were observed in a meta-analysis of central retinal vein occlusion (CRVO) and when comparing Caucasian subgroups to populationbased controls. These data demonstrate that the G/A genotype of Factor V G1691A is associated with an increased risk of RVO/CRVO in a Caucasian population.

\section{INTRODUCTION}

Retinal vein occlusion (RVO) is a multifactorial vascular disease characterized by retinal blood stasis, venous tortuous expansion, retinal hemorrhage, and edema that can cause loss of visual acuity loss or blindness [1]. There are two main types of RVO, branch retinal vein occlusion (BRVO) and central retinal vein occlusion (CRVO), which are classified according to the sites of occlusion $[2,3]$. Systemic vascular disorders including hypertension, arteriosclerosis, and diabetes mellitus, as well as genetic background and environmental factors have been associated with the risk of RVO $[4,5]$. Single nucleotide polymorphisms (SNPs) in several hemostasis-associated genes such as Factor V, Prothrombin (Factor II), and PAI1 , may contribute to the pathogenesis of $\operatorname{RVO}[4,6]$.

Factor $\mathrm{V}$, a co-factor in the prothrombinase complex, has an essential role in blood coagulation, and modulates the conversion of prothrombin to thrombin [7]. Factor $V$ G1691A (Factor $V$ Leiden or R506Q), is a frequently observed mutation in Factor $V$ that has been associated with activated protein $\mathrm{C}$ (APC) resistance and several diseases including Budd-Chiari syndrome, portal vein thrombosis, and RVO [8-10]. The most recent metaanalysis of genetic variants associated with RVO was published in 2013 and involved 21 case-control studies [11]. Therefore, we performed an updated meta-analysis of 37 case-control studies under all genetic models.

\section{RESULTS}

Identification of eligible case-control studies

A flow diagram showing the process by which we identified eligible case-control studies is shown in Figure 1. We initially found 498 articles in the PubMed $(n=102)$, Embase $(n=111)$, and Web of Science (WOS, $n=285$ ) databases. We removed 120 duplicate articles, and excluded 179 articles (69 review articles or editorials, 63 case or trial reports, 43 meeting abstract or posters, and four meta-analyses). We also excluded 22 articles that were based on cell or animal data, and 134 articles that involved unrelated diseases, genes, or SNPs. Of the remaining 43 articles, three were excluded due to genotype departure from Hardy-Weinberg equilibrium (HWE) and three due to a lack of available genotype data. We included 37 articles that contained 2, 510 cases and 3,466 controls $[6,11-46]$ in our meta-analysis. Basic study information is shown in Table 1. All studies had Newcastle-Ottawa Scale (NOS) scores above five.

\section{Overall meta-analysis}

We analyzed the association between Factor $V$ G1691A and RVO susceptibility using a fixed-effects model and Mantel-Haenszel statistics. We did not observe a high degree of heterogeneity between the various 
models (AA vs. GG, AA vs. GG+GA, A vs. G (carrier) [all $\mathrm{I}^{2}<50 \%, P$ value of the heterogeneity test $\left.\left(P_{\mathrm{H}}\right)>0.1\right]$ (Table 2). An increased risk of RVO in cases compared to controls was observed under allele, heterozygote, dominant, and carrier models (G vs. A, $P$ value of the association test $\left[P_{\mathrm{A}}\right]<0.001$, odds ratio $[\mathrm{OR}]=1.98$; GA vs. GG, $P_{\mathrm{A}}<0.001, \mathrm{OR}=1.90 ; \mathrm{GA}+\mathrm{AA}$ vs. GG, $P_{\mathrm{A}}<$ $0.001, \mathrm{OR}=2.01$; A vs. $\mathrm{G}$ carrier, $\left.P_{\mathrm{A}}<0.001, \mathrm{OR}=1.96\right)$, but not homozygote and recessive models (all $P_{\mathrm{A}}>0.05$ ). Forest plots are shown for the meta-analysis under A vs. G (allele) (Figure 2), GA+AA vs. GG (Figure 3), AA vs. GG (Supplementary Figure 1), GA vs. GG (Supplementary Figure 2), AA vs. GG+GA (Supplementary Figure 3), and A vs. G (carrier) (Supplementary Figure 4) models. These data indicate that the G/A genotype of Factor $V$ G1691A is associated with an increased risk of RVO.

\section{Subgroup meta-analysis}

We next performed a subgroup analysis based on ethnicity, source of controls (population-based [PB] or hospital-based $[\mathrm{HB}])$, and disease type (BRVO/CRVO) under all genetic models. Factor $V$ G1691A was associated with an increased risk of RVO compared to controls in a Caucasian population under A vs. G (allele) (Table 3, $\left.P_{\mathrm{A}}<0.001, \mathrm{OR}=1.75\right), \mathrm{GA}$ vs. GG $\left(P_{\mathrm{A}}<0.001, \mathrm{OR}=\right.$ $1.66), \mathrm{GA}+\mathrm{AA}$ vs. $\mathrm{GG}\left(P_{\mathrm{A}}<0.001, \mathrm{OR}=1.88\right)$, and A vs. $\mathrm{G}$ (carrier) $\left(P_{\mathrm{A}}<0.001, \mathrm{OR}=1.66\right)$ models. Factor $V$

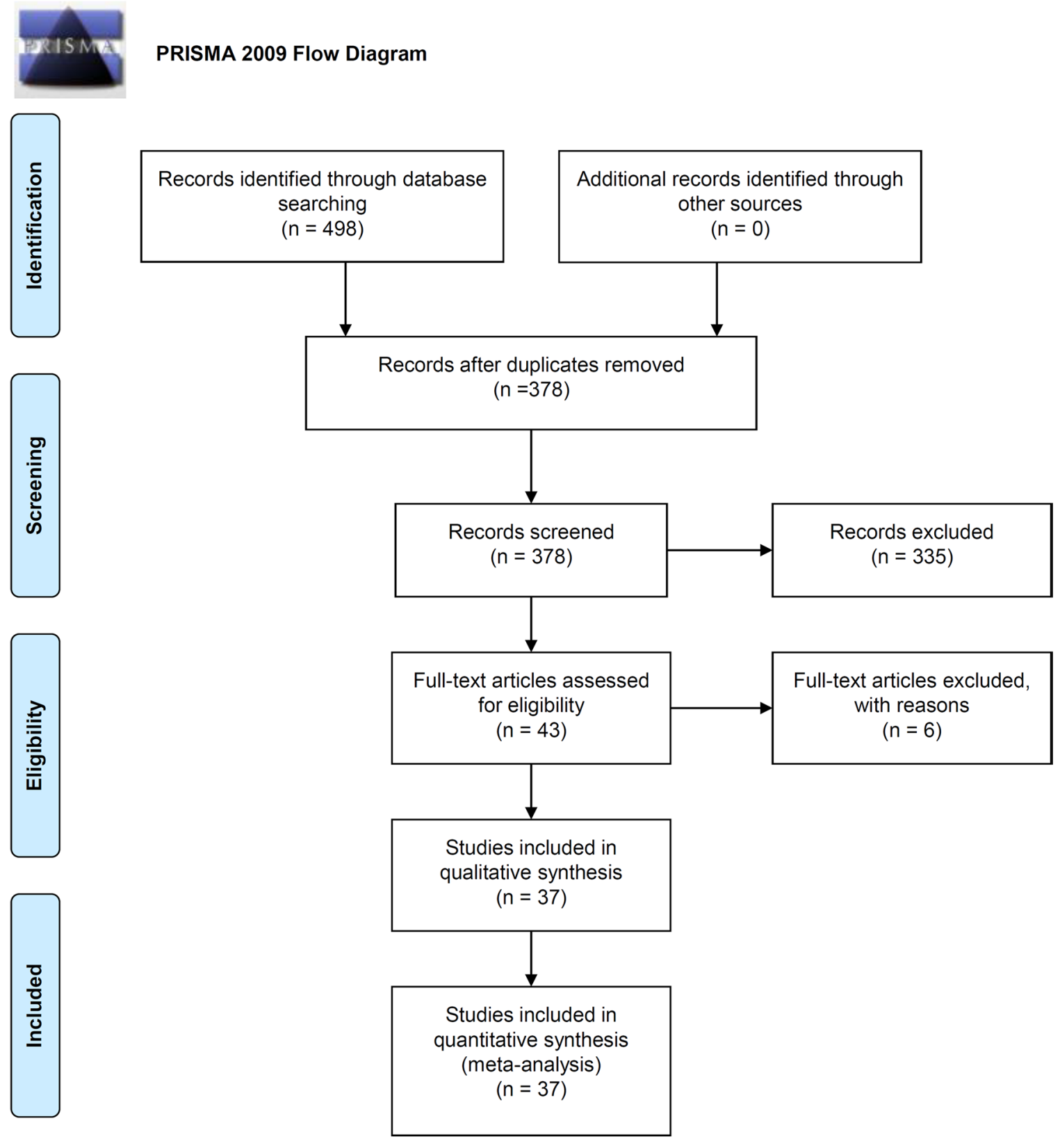

Figure 1: PRISMA 2009 flow diagram showing the process for identifying eligible case-control studies. 
Table 1: Basic information for the studies included in the meta-analysis

\begin{tabular}{|c|c|c|c|c|c|c|c|c|c|c|c|c|c|c|c|}
\hline \multirow{2}{*}{$\begin{array}{l}\text { First } \\
\text { author }\end{array}$} & \multirow{2}{*}{ Year } & \multirow{2}{*}{ Country } & \multirow{2}{*}{ Ethnicity } & \multicolumn{4}{|c|}{ Cases } & \multirow{2}{*}{$\begin{array}{l}\text { Disease } \\
\text { type }\end{array}$} & \multicolumn{4}{|c|}{ Controls } & \multirow{2}{*}{ Assay } & \multirow{2}{*}{ Source } & \multirow{2}{*}{ NOS } \\
\hline & & & & $\mathbf{G} / \mathbf{G}$ & G/A & $\mathbf{A} / \mathbf{A}$ & Total & & G/G & G/A & $\mathbf{A} / \mathbf{A}$ & Total & & & \\
\hline Adamczuk & 2002 & Argentina & Caucasian & 37 & 0 & 0 & 37 & CRVO & 140 & 4 & 0 & 144 & PCR-RFLP & PB & 8 \\
\hline Albisinni & 1998 & Italy & Caucasian & 32 & $4 *$ & - & 36 & RVO & 67 & $1^{*}$ & - & 68 & PCR-RFLP & $\mathrm{HB}$ & 7 \\
\hline \multirow[t]{2}{*}{ Arsene } & 2005 & France & Caucasian & 143 & 10 & 0 & 153 & CRVO & 172 & 8 & 0 & 180 & PCR-RFLP & $\mathrm{PB} / \mathrm{HB}$ & 6 \\
\hline & & & Caucasian & 79 & 2 & 0 & 81 & BRVO & 172 & 8 & 0 & 180 & PCR-RFLP & $\mathrm{PB} / \mathrm{HB}$ & \\
\hline \multirow[t]{2}{*}{ Batioglu } & 2003 & Turkey & Caucasian & 8 & $7 *$ & - & 15 & RVO & 257 & $28 *$ & - & 285 & PCR-RFLP & $\mathrm{PB}$ & 7 \\
\hline & & & Caucasian & 6 & $9 *$ & - & 15 & BRVO & 257 & $28 *$ & - & 285 & PCR-RFLP & PB & \\
\hline Biancardi & 2007 & Brazil & Caucasian & 53 & 2 & 0 & 55 & RVO & 55 & 0 & 0 & 55 & PCR-RFLP & HB & 6 \\
\hline Bombeli & 2002 & Switzerland & Caucasian & 65 & $3 *$ & - & 68 & RVO & 112 & $8^{*}$ & - & 120 & PCR-RFLP & PB & 7 \\
\hline Ciardella & 1998 & USA & Caucasian & 29 & 1 & 0 & 30 & RVO & 46 & 1 & 0 & 47 & PCR-RFLP & $\mathrm{HB}$ & 7 \\
\hline Cruciani & 2003 & Italy & Caucasian & 29 & 0 & 0 & 29 & RVO & 61 & 1 & 0 & 62 & PCR-RFLP & PB & 7 \\
\hline De Polo & 2015 & Italy & Caucasian & 32 & 5 & 0 & 37 & RVO & 43 & 2 & 0 & 45 & PCR-RFLP & PB & 7 \\
\hline Delahousse & 1998 & France & Caucasian & 76 & 7 & 0 & 83 & RVO & 60 & 0 & 0 & 60 & PCR-RFLP & PB & 6 \\
\hline \multirow[t]{2}{*}{ Demirci } & 1999 & Turkey & Caucasian & 20 & 3 & 0 & 23 & CRVO & 109 & 11 & 0 & 120 & PCR-RFLP & PB & 7 \\
\hline & & & Caucasian & 24 & 1 & 0 & 25 & BRVO & 109 & 11 & 0 & 120 & PCR-RFLP & PB & \\
\hline Di Capua & 2010 & Italy & Caucasian & 109 & 8 & 0 & 117 & RVO & 191 & 11 & 0 & 202 & PCR-RFLP & PB & 9 \\
\hline Dixon & 2016 & USA & Caucasian & 52 & 8 & 0 & 60 & RVO & 60 & 2 & 0 & 62 & PCR & PB & 7 \\
\hline Dodson & 2003 & UK & Caucasian & 39 & 1 & 0 & 40 & RVO & 39 & 1 & 0 & 40 & PCR-RFLP & PB & 9 \\
\hline Faude & 1999 & Germany & Caucasian & 101 & 6 & 0 & 107 & CRVO & 66 & 4 & 0 & 70 & PCR-RFLP & PB & 6 \\
\hline Giannaki & 2013 & Greece & Caucasian & 47 & 4 & 0 & 51 & RVO & 46 & 5 & 0 & 51 & CVD Strip Assay & PB & 8 \\
\hline Glueck & 1999 & USA & Caucasian & 14 & 3 & 0 & 17 & RVO & 226 & 7 & 0 & 233 & PCR-RFLP & PB & 8 \\
\hline Glueck & 2005 & USA & Caucasian & 20 & 3 & 0 & 23 & RVO & 43 & 1 & 0 & 44 & PCR & PB & 7 \\
\hline Gori & 2004 & Italy & Caucasian & 99 & 13 & 0 & 112 & RVO & 107 & 5 & 0 & 112 & PCR-RFLP & PB & 9 \\
\hline Graham & 1996 & Australia & Caucasian & 22 & 1 & 0 & 23 & CRVO & 109 & 4 & 0 & 113 & PCR-RFLP & PB & 7 \\
\hline \multirow[t]{2}{*}{ Greiner } & 1999 & Germany & Caucasian & 35 & 12 & 1 & 48 & CRVO & 32 & 3 & 0 & 35 & PCR & HB & 5 \\
\hline & & & Caucasian & 27 & 6 & 0 & 33 & BRVO & 32 & 3 & 0 & 35 & PCR & HB & \\
\hline Horoz & 2005 & Turkey & Caucasian & 29 & 2 & 1 & 32 & BRVO & 27 & 3 & 0 & 30 & NR & PB & 8 \\
\hline Johnson & 2001 & Canada & Caucasian & 43 & 1 & 0 & 44 & CRVO & 68 & 3 & 0 & 71 & PCR-RFLP & HB & 6 \\
\hline \multirow[t]{2}{*}{ Kalayci } & 1999 & Turkey & Caucasian & 48 & 4 & 0 & 52 & RVO & 75 & 6 & 0 & 81 & PCR-RFLP & PB & 7 \\
\hline & & & Caucasian & 24 & 3 & 0 & 27 & BRVO & 75 & 6 & 0 & 81 & PCR-RFLP & PB & \\
\hline $\begin{array}{l}\text { Karska- } \\
\text { Basta }\end{array}$ & 2013 & Poland & Caucasian & 53 & 6 & 0 & 59 & RVO & 50 & 9 & 0 & 59 & PCR & PB & 8 \\
\hline Koylu & 2017 & Turkey & Caucasian & 43 & 3 & 3 & 49 & RVO & 64 & 4 & 0 & 68 & PCR-RFLP & PB & 7 \\
\hline Kuhli & 2002 & Germany & Caucasian & 129 & 11 & 2 & 142 & RVO & 122 & 6 & 0 & 128 & PCR-RFLP & PB & 7 \\
\hline $\begin{array}{l}\text { Kuhli- } \\
\text { Hattenbach }\end{array}$ & 2017 & Germany & Caucasian & 34 & 8 & 0 & 42 & RVO & 230 & 11 & 0 & 241 & PCR-RFLP & PB & 7 \\
\hline Lahey & 2002 & USA & Mixed & 53 & 2 & 0 & 55 & CRVO & 21 & 0 & 0 & 21 & $\begin{array}{c}\text { Coatest APC } \\
\text { Resistance V Kit }\end{array}$ & $\mathrm{PB}$ & 7 \\
\hline Larsson & 1997 & Sweden & Caucasian & 74 & 8 & 1 & 83 & CRVO & 90 & 10 & 1 & 101 & PCR-RFLP & PB & 6 \\
\hline Marcucci & 2001 & Italy & Caucasian & 88 & 12 & 0 & 100 & CRVO & 96 & 4 & 0 & 100 & PCR-RFLP & PB & 7 \\
\hline Marcucci & 2003 & Italy & Caucasian & 47 & $8 *$ & - & 55 & RVO & 59 & $2 *$ & - & 61 & PCR-RFLP & PB & 8 \\
\hline Mrad & 2014 & Tunisie & African & 46 & 42 & 0 & 88 & RVO & 94 & 5 & 0 & 99 & PCR-RFLP & PB & 8 \\
\hline Rehak & 2010 & Czech & Caucasian & 74 & $5^{*}$ & - & 79 & CRVO & 56 & $4 *$ & - & 60 & $\begin{array}{l}\text { Allele-specific } \\
\text { PCR }\end{array}$ & HB & 7 \\
\hline
\end{tabular}




\begin{tabular}{lccccccccccccccccc} 
& & & Caucasian & 36 & $6^{*}$ & - & 42 & BRVO & 56 & $4 *$ & - & 60 & Allele-specific & HCR \\
Risse & 2014 & Germany & Caucasian & 83 & 3 & 0 & 86 & CRVO & 39 & 1 & 0 & 40 & PCR & PB & 7 \\
& & & Caucasian & 45 & 2 & 0 & 47 & BRVO & 39 & 1 & 0 & 40 & PCR & PB \\
Salomon & 1998 & Israel & Asian & 95 & $7 *$ & - & 102 & RVO & 96 & $9 *$ & - & 105 & PCR-RFLP & HB & 6 \\
Yioti & 2013 & Greece & Caucasian & 47 & 1 & 0 & 48 & RVO & 53 & 0 & 0 & 53 & CVD Strip Assays & HB & 6 \\
\hline
\end{tabular}

RFLP, restriction fragment-length polymorphism; CVD, Cardiovascular disease panel; *, the frequency of the G/A+A/A genotype.

Table 2: Meta-analysis of the association between Factor V G1691A and RVO

\begin{tabular}{|c|c|c|c|c|c|c|c|c|c|c|c|}
\hline \multirow{2}{*}{ Genetic models } & \multirow{2}{*}{$\begin{array}{l}\text { Case-control } \\
\text { study number }\end{array}$} & \multirow{2}{*}{$\begin{array}{l}\text { Sample size } \\
\text { Case/control }\end{array}$} & \multicolumn{2}{|c|}{ Association test } & \multicolumn{2}{|c|}{$\begin{array}{c}\text { Heterogeneity } \\
\text { test }\end{array}$} & \multirow[b]{2}{*}{ Model } & \multicolumn{2}{|c|}{ Begg's test } & \multicolumn{2}{|c|}{ Egger's test } \\
\hline & & & OR $(95 \% \mathrm{CI})$ & $P_{\mathrm{A}}$ & $I^{2}(\%)$ & $P_{\mathrm{H}}$ & & $\mathrm{z}$ & $P_{B}$ & t & $P_{\mathrm{E}}$ \\
\hline A vs. G (allele) & 31 & $2,113 / 2,767$ & $1.98(1.45 \sim 2.72)$ & $<0.001$ & $32.1 \%$ & 0.046 & Random & 0.54 & 0.587 & -0.13 & 0.897 \\
\hline AA vs. GG & 5 & $387 / 362$ & $3.38(0.93 \sim 12.35)$ & 0.065 & $0.0 \%$ & 0.855 & Fixed & -0.24 & 1.000 & 0.22 & 0.843 \\
\hline GA vs. GG & 31 & $2,113 / 2,767$ & $1.90(1.34 \sim 2.70)$ & $<0.001$ & $39.8 \%$ & 0.013 & Random & 0.68 & 0.497 & -0.28 & 0.784 \\
\hline GA+AA vs. GG & 37 & $2,510 / 3,466$ & $2.01(1.46 \sim 2.78)$ & $<0.001$ & $43.7 \%$ & 0.003 & Random & 0.67 & 0.505 & 0.08 & 0.937 \\
\hline AA vs. $\mathbf{G G}+\mathbf{G A}$ & 5 & $387 / 362$ & $3.30(0.90 \sim 12.04)$ & 0.071 & $0.0 \%$ & 0.843 & Fixed & -0.24 & 1.000 & 0.16 & 0.882 \\
\hline A vs. G (carrier) & 31 & $2,113 / 2,767$ & $1.96(1.55 \sim 2.48)$ & $<0.001$ & $18.0 \%$ & 0.189 & Fixed & 0.61 & 0.541 & -0.09 & 0.928 \\
\hline
\end{tabular}

$P_{\mathrm{B}}, P$ value of Begg's test; $P_{\mathrm{E}}, P$ value of Egger's test.

G1691A was also associated with an increased risk of RVO among cases compared to PB controls. Eight BRVO and 13 CRVO studies were included in the disease subgroup meta-analysis. We observed an increased risk of CRVO, but not BRVO, under allele, heterozygote, dominant, and carrier models. Forest plots for the subgroup analysis under the A vs. G (allele) and GA+AA vs. GG models are shown in Supplementary Figures 5-6. Our data indicate G/A genotype of Factor $V$ G1691A is associated with an increased risk of RVO (particularly CRVO) in Caucasians.

\section{Publication bias and sensitivity analysis}

Our analysis indicated there was no publication bias (Table 2, all $P_{\text {Begg }}>0.05$ and $P_{\text {Egger }}>0.05$ ). Begg's funnel plots with pseudo $95 \%$ confidence limits under the A vs. G (allele) and GA+AA vs. GG models are shown in Figure 4. Sensitivity analysis (Figure 5 for the GA+AA vs. GG model and data not shown) was indicative of stable statistical results.

\section{DISCUSSION}

The G/A genotype of Factor $V$ G1691A was previously associated with an increased risk of RVO in
French [14] and Tunisian [43] populations. However, no differences in the frequency of the Factor V G1691A polymorphism between RVO cases and controls were reported in studies of Turkish populations [22, 32, 36]. Janssen et al. performed a meta-analysis of 12 studies [12, $13,17,22,27,33,34,39,41,42,46,47]$ and found that the Factor $V$ Leiden mutation $(\mathrm{G} / \mathrm{A}+\mathrm{A} / \mathrm{A})$ was associated with an increased risk of RVO [48]. Rehak et al. performed a meta-analysis of 18 studies [13, 14, 17, 19, 22, 29, 31, $34,37,40-42,47,49-53]$ and reported similar results [52]. Finally, Yioti et al. performed a meta-analysis of 21 case-control studies [11-14, 16-19, 21-23, 28, 29, 33, 34, $37,41,42,51,53,54]$ and demonstrated that the Factor $V$ Leiden mutation was associated with an increased risk of RVO [11].

The A/A genotype of Factor $V$ was previously observed in several studies [31, 32, 36, 37, 40]. However, only the contribution of G/A+A/A genotype of Factor $V$ G1691A to RVO was described; the roles of the individual G/A or A/A genotypes were not investigated. Several factors including ethnic background, source of controls ( $\mathrm{PB} / \mathrm{HB})$, and disease type (BRVO/CRVO) were also not sufficiently analyzed in previous studies [11, 48, 52]. Therefore, we performed a meta-analysis of 37 casecontrol studies, under allele (A vs. G), homozygote (AA 


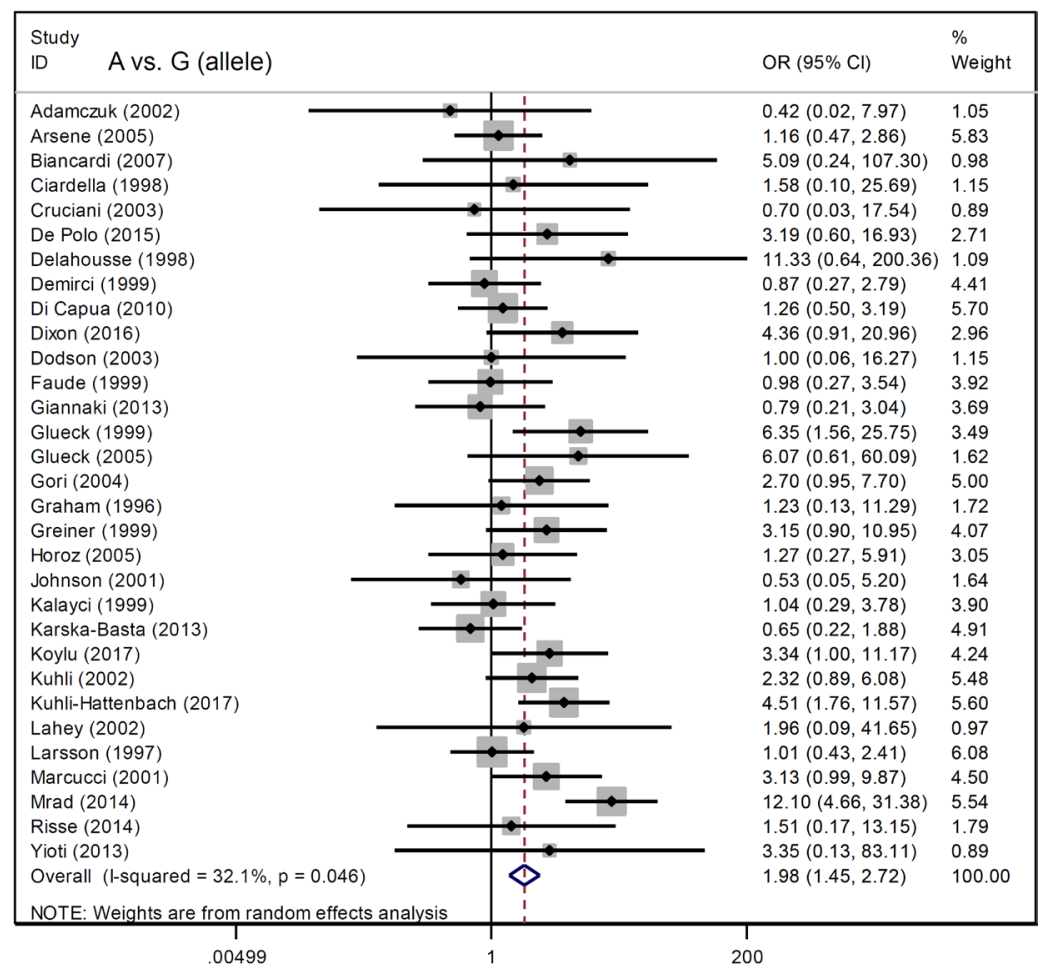

Figure 2: Forest plot data for the meta-analysis under the A vs. G (allele) model.

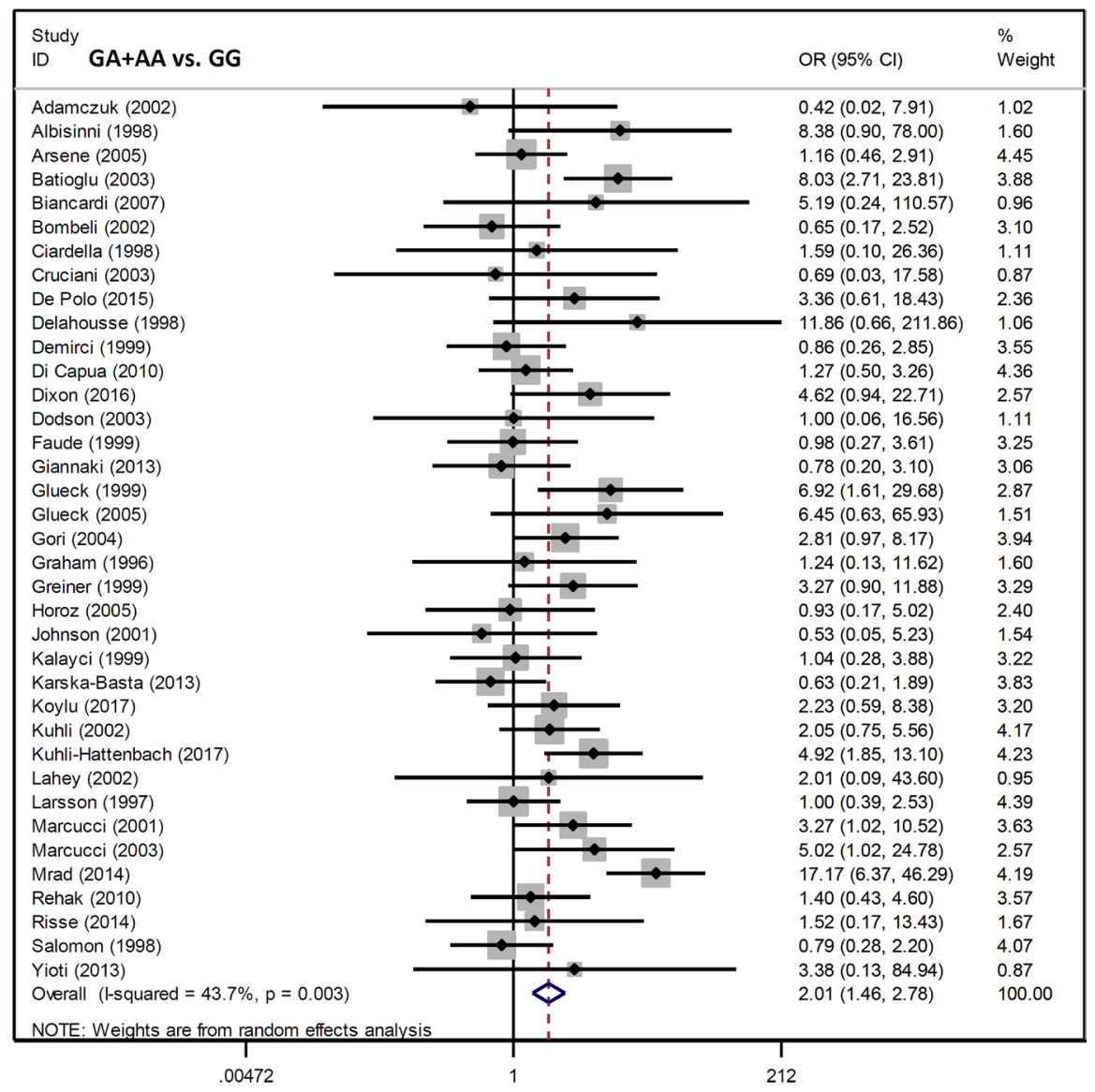

Figure 3: Forest plot data for the meta-analysis under the GA+AA vs. GG model. 
Table 3: Subgroup analysis of the association between Factor V G1691A and RVO

\begin{tabular}{|c|c|c|c|c|c|c|c|}
\hline \multirow{2}{*}{ Genetic model } & \multirow{2}{*}{ Subgroup } & \multirow{2}{*}{$\begin{array}{l}\text { Case-control } \\
\text { study number }\end{array}$} & \multicolumn{2}{|c|}{ Association test } & \multirow{2}{*}{$\begin{array}{l}\text { Sample size } \\
\text { Case/ Control }\end{array}$} & \multicolumn{2}{|c|}{ Heterogeneity test } \\
\hline & & & OR $(95 \% \mathrm{CI})$ & $P_{\mathrm{A}}$ & & $I^{2}(\%)$ & $P_{\mathrm{H}}$ \\
\hline \multirow[t]{5}{*}{ A vs. G (allele) } & Caucasian & 29 & $1.75(1.35 \sim 2.28)$ & $<0.001$ & $1,970 / 2,647$ & $4.0 \%$ & 0.405 \\
\hline & BRVO & 6 & $1.11(0.59 \sim 2.08)$ & 0.750 & $245 / 486$ & $0.0 \%$ & 0.719 \\
\hline & CRVO & 12 & $1.66(1.14 \sim 2.42)$ & 0.008 & $840 / 1,030$ & $0.0 \%$ & 0.744 \\
\hline & PB & 25 & $2.03(1.41 \sim 2.92)$ & $<0.001$ & $1,621 / 2,326$ & $40.6 \%$ & 0.019 \\
\hline & HB & 5 & $2.29(0.91 \sim 5.77)$ & 0.080 & $258 / 261$ & $0.0 \%$ & 0.697 \\
\hline \multirow[t]{3}{*}{ AA vs. GG } & Caucasian & 5 & $3.38(0.93 \sim 12.35)$ & 0.065 & $287 / 362$ & $0.0 \%$ & 0.855 \\
\hline & CRVO & 3 & $1.70(0.30 \sim 9.73)$ & 0.548 & $212 / 171$ & $0.0 \%$ & 0.931 \\
\hline & PB & 4 & $3.90(0.95 \sim 16.06)$ & 0.060 & $306 / 327$ & $0.0 \%$ & 0.768 \\
\hline \multirow[t]{5}{*}{ GA vs. GG } & Caucasian & 29 & $1.66(2.16 \sim 1.28)$ & $<0.001$ & $1,970 / 2,647$ & $5.5 \%$ & 0.381 \\
\hline & BRVO & 6 & $1.01(0.52 \sim 1.95)$ & 0.987 & $245 / 486$ & $0.0 \%$ & 0.643 \\
\hline & CRVO & 12 & $1.65(1.12 \sim 2.44)$ & 0.012 & $840 / 1,030$ & $0.0 \%$ & 0.780 \\
\hline & PB & 25 & $1.93(1.28 \sim 2.90)$ & 0.002 & $1,621 / 2,326$ & $48.2 \%$ & 0.004 \\
\hline & $\mathrm{HB}$ & 5 & $2.25(0.87 \sim 5.79)$ & 0.093 & $258 / 261$ & $0.0 \%$ & 0.703 \\
\hline \multirow[t]{5}{*}{ GA+AA vs. GG } & Caucasian & 34 & $1.88(1.42 \sim 2.50)$ & $<0.001$ & $2,265 / 3,241$ & $22.0 \%$ & 0.128 \\
\hline & BRVO & 8 & $1.89(1.15 \sim 3.11)$ & 0.011 & $302 / 831$ & $60.6 \%$ & 0.013 \\
\hline & CRVO & 13 & $1.60(1.11 \sim 2.33)$ & 0.013 & $919 / 1.090$ & $0.0 \%$ & 0.761 \\
\hline & PB & 28 & $2.13(1.45 \sim 3.13)$ & $<0.001$ & $1,759 / 2,792$ & $50.6 \%$ & 0.001 \\
\hline & HB & 8 & $1.59(0.89 \sim 2.84)$ & 0.117 & $517 / 494$ & $0.0 \%$ & 0.440 \\
\hline \multirow[t]{3}{*}{ AA vs. GG+GA } & Caucasian & 5 & $3.39(0.90 \sim 12.04)$ & 0.071 & $287 / 362$ & $0.0 \%$ & 0.843 \\
\hline & CRVO & 3 & $1.52(0.26 \sim 8.74)$ & 0.639 & $212 / 171$ & $0.0 \%$ & 0.958 \\
\hline & PB & 4 & $3.89(0.94 \sim 16.03)$ & 0.060 & $306 / 327$ & $0.0 \%$ & 0.773 \\
\hline \multirow[t]{5}{*}{ A vs. $G$ (carrier) } & Caucasian & 29 & $1.66(1.29 \sim 2.14)$ & $<0.001$ & $1,970 / 2,647$ & $0.0 \%$ & 0.632 \\
\hline & BRVO & 6 & $1.05(0.54 \sim 2.01)$ & 0.892 & $245 / 486$ & $0.0 \%$ & 0.764 \\
\hline & CRVO & 12 & $1.58(1.07 \sim 2.33)$ & 0.020 & $840 / 1,030$ & $0.0 \%$ & 0.860 \\
\hline & $\mathrm{PB}$ & 25 & $2.03(1.57 \sim 2.61)$ & $<0.001$ & $1,621 / 2,326$ & $28.3 \%$ & 0.095 \\
\hline & $\mathrm{HB}$ & 5 & $2.16(0.90 \sim 5.20)$ & 0.085 & $258 / 261$ & $0.0 \%$ & 0.743 \\
\hline
\end{tabular}

vs. GG), heterozygote (GA vs. GG), dominant (GA+AA vs. GG), recessive (AA vs. GG+GA), and carrier (A vs. $\mathrm{G})$ models. Our data indicate that the presence of a single Factor $V$ Leiden allele increases the risk of RVO. The G/A genotype of Factor $V$, but not the A/A genotype, was an inherited risk factor for RVO in a Caucasian population. Moreover, when we stratified by type of RVO, heterozygosity was associated with an increased risk of CRVO, but not BRVO. The mechanisms underlying the association between Factor $V$ G1691A and RVO have not been elucidated. It is possible that Factor $V$ mutations lead to resistance to anticoagulant processing, and activated APC resistance or protein S deficiency may be the key points, which are worthy of future experiment data. 

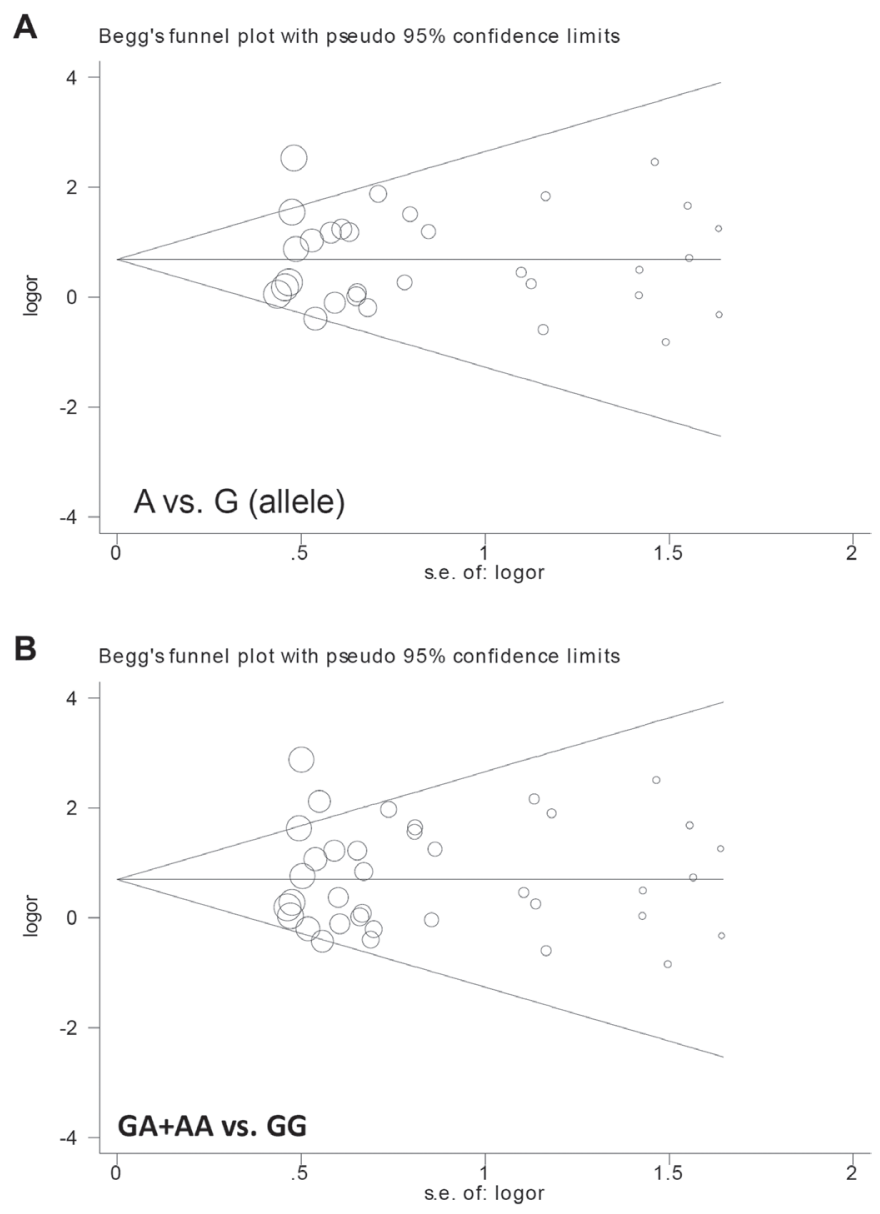

Figure 4: Begg's funnel plot data with pseudo 95\% confidence limits. (A) A vs. G (allele); (B) GA+AA vs. GG.

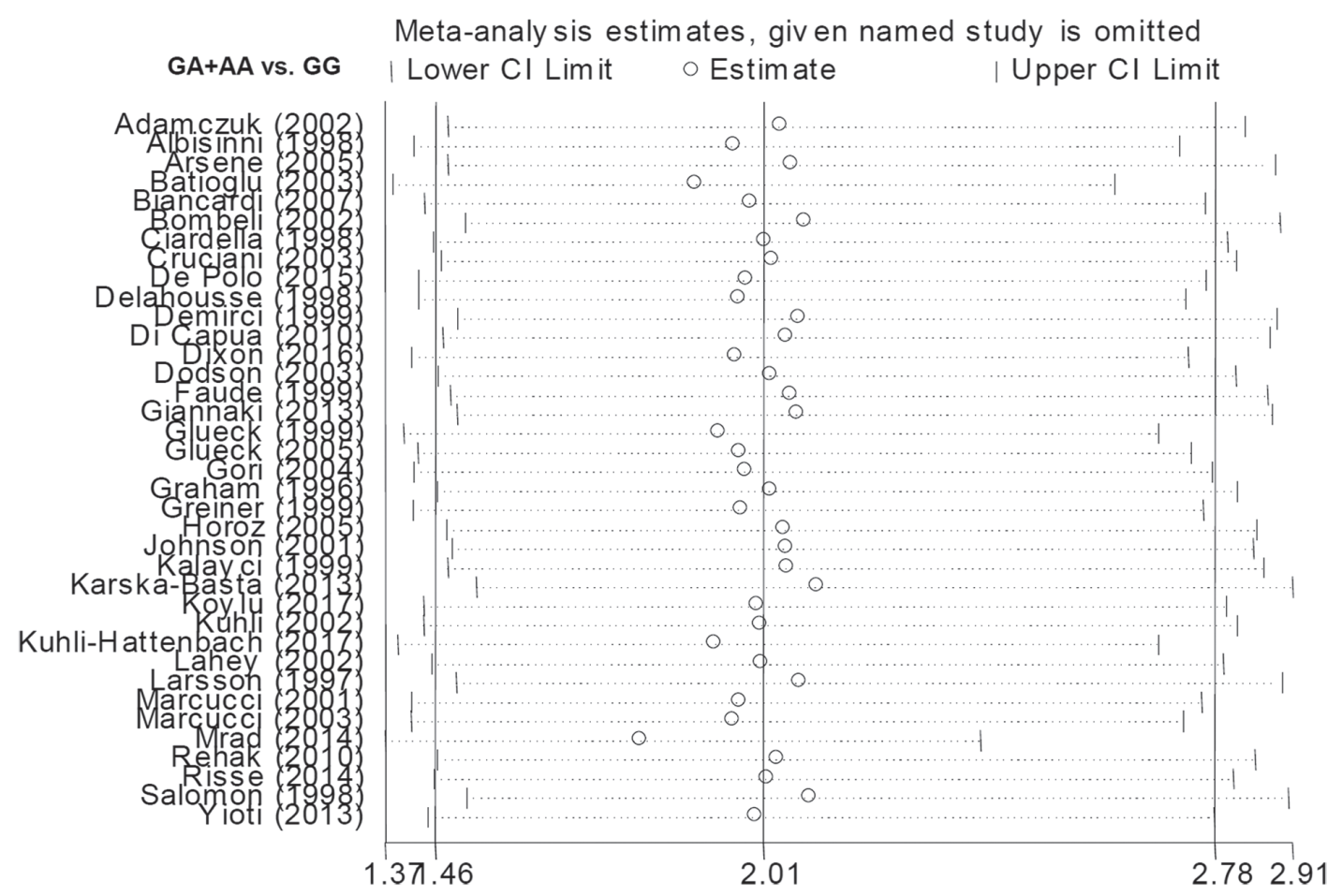

Figure 5: Sensitivity analysis data under the GA+AA vs. GG model. 
Our study had several advantages. First, we performed a quantitative analysis of a large number of case-control studies selected from three independent databases. Second, we excluded studies involving genotype data that deviated from Hardy-Weinberg Equilibrium, which confirmed the balance of gene frequency and genotype frequency, and enabled rigorous statistical analysis. Third, under the guideline of our strict inclusion and exclusion criteria, the enrolled case-control studies exhibit the high publication quality. Among them, we found that population-based control data is involved in most of studies. The data from the comparison between RVO case and healthy control subjects from the normal population is more helpful to drive a more reasonable statistical assessment for the genetic role of Factor $V$ Leiden allele in the clinical RVO cases. We also performed subgroup analyses according to ethnicity (Caucasian/ Asian), source of controls $(\mathrm{PB} / \mathrm{HB})$, and disease type (BRVO/CRVO). Finally, we detected no publication bias and demonstrated stable statistical results in a sensitivity analysis.

Our study also had several disadvantages. First, the sample size of the included case-control studies was relatively small, which limited the statistical power in the subgroup meta-analysis. For example, only one casecontrol study was enrolled in the subgroup analysis for the association between Factor $V$ G1691A and susceptibility to RVO in an Asian population [46]. Second, although there was no clear association between the A/A genotype of Factor $V$ G1691A and the risk of RVO, we cannot exclude the potential genetic effect of homozygosity. The low prevalence of the A/A genotype may have contributed to the underpowered meta-analysis. Third, only the G1691A SNP was investigated in our study due to data availability. We did not analyze the role of other SNPs (e.g. G4070A), or the combination of Factor $V$ and other relative genes such as MTHFR and prothrombin. Fourth, the main clinical types of retinal vein occlusion, namely BRVO and CRVO, and other uncommon types, such as bilateral RVO, exhibit the differences or complexity of physiopathology [1-3, 55]. Unfortunately, we failed to obtain the SNP data of the association between Factor $V$ Leiden and bilateral RVO risk. Confounding factors such as sex, age of onset, family history, lifestyle, clinical type, and complications should be investigated in future metaanalyses of a larger number of subjects with different types of RVO. Finally, heterogeneity was observed between the A vs. G (allele), GA vs. GG, GA+AA vs. GG genetic models, which could have biased our analysis. However, no heterogeneity was observed in the subgroup analysis of Caucasians (all $\mathrm{I}^{2}<50 \%, P_{\mathrm{H}}>0.1$ ). Similarly, we observed no heterogeneity between the BRVO/CRVO subgroups, with the exception of the BRVO subgroup under the GA+AA vs. GG models. Thus, ethnicity and disease type may have contributed to the observed heterogeneity. Our meta-analysis indicates that the G/A genotype of Factor $V$ G1691A is associated with an increased risk of RVO, particularly CRVO, in Caucasians.

\section{MATERIALS AND METHODS}

\section{Database retrieval and article screening}

Using the guidelines of the "Preferred Reporting Items for Systematic Reviews and Meta-Analyses (PRISMA)" [56], we retrieved articles published before July 27, 2017 from the PubMed, Embase, and WOS databases. Search terms for PubMed included the following: $((()(()(($ Retinal Vein Occlusion[MeSH Terms]) OR occlusion, retinal vein) OR occlusions, retinal vein) OR retinal vein thrombosis) OR retinal vein thromboses) OR thromboses, retinal vein) OR vein thromboses, retinal) OR vein thrombosis, retinal) OR thrombosis, retinal vein)) AND $(((()((($ Factor $V$ [Other Term] $)$ OR Proaccelerin) OR AC Globulin) OR Coagulation Factor V) OR Factor $V$, Coagulation) OR Factor Pi) OR Blood Coagulation Factor V) OR FV Leiden) OR Factor V G1691A). We excluded duplicate articles, and then screened and removed ineligible articles using the following exclusion criteria: (1) review article or editorial, (2) case or trial report, (3) meeting abstract or poster, (4) meta-analysis, (5) cell- or animal-based study, (6) unrelated disease, gene, or SNP (7) departure from HWE, and (8) lack of available genotype data.

\section{Data extraction and NOS assessment}

Three authors independently extracted data from eligible articles including the name of the first author, publication year, country, ethnicity of the study population, genotype frequencies, disease type, genotyping assay, study number, sample size of case/control populations, and source of controls. We assessed the methodological quality of eligible studies using the NOS system (http://www.ohri. ca/programs/clinical_epidemiology/oxford.asp).

\section{Statistical analysis}

Mantel-Haenszel statistical analysis under fixed- or random-effect models was performed with the Stata/SE 12.0 software (StataCorp, USA). A fixed-effect model was utilized where Cochran's Q statistic $\left(P_{\mathrm{H}}\right)>0.1$ or $\mathrm{I}^{2}<50$ $\%$. ORs, $95 \%$ CIs, and $P_{\mathrm{A}}$ values were calculated in allele (A vs. G), homozygote (AA vs. GG), heterozygote (GA vs. $\mathrm{GG}$ ), dominant (GA+AA vs. GG), recessive (AA vs. GG $+\mathrm{GA}$ ), and carrier (A vs. G) models. Subgroup analysis was performed according to ethnicity, source of controls (PB/HB), and disease type (BRVO/CRVO) under all genetic models. Publication bias was evaluated using Begg's and Egger's tests and sensitivity analysis was performed. 


\section{CONFLICTS OF INTEREST}

The authors declare that there are no conflicts of interest.

\section{REFERENCES}

1. Sawada O, Ohji M. Retinal Vein Occlusion. Dev Ophthalmol. 2016; 55:147-153.

2. Ashraf M, Souka AA, Singh RP. Central retinal vein occlusion: modifying current treatment protocols. Eye (Lond). 2016; 30:505-514.

3. Li J, Paulus YM, Shuai Y, Fang W, Liu Q, Yuan S. New Developments in the Classification, Pathogenesis, Risk Factors, Natural History, and Treatment of Branch Retinal Vein Occlusion. J Ophthalmol. 2017; 2017:4936924.

4. Chak M, Wallace GR, Graham EM, Stanford MR. Thrombophilia: genetic polymorphisms and their association with retinal vascular occlusive disease. $\mathrm{Br} \mathrm{J}$ Ophthalmol. 2001; 85:883-886.

5. Bremond-Gignac D. Investigational drugs for retinal vein occlusion. Expert Opin Investig Drugs. 2016; 25: 841-850.

6. Giannaki K, Politou M, Rouvas A, Merkouri E, Travlou A, Theodosiadis P, Gialeraki A. Retinal vein occlusion: genetic predisposition and systemic risk factors. Blood Coagul Fibrinolysis. 2013; 24:279-283.

7. Somajo S, Koshiar RL, Norstrom E, Dahlback B. Protein $\mathrm{S}$ and factor $\mathrm{V}$ in regulation of coagulation on platelet microparticles by activated protein C. Thromb Res. 2014; 134:144-152.

8. Campello E, Spiezia L, Simioni P. Diagnosis and management of factor V Leiden. Expert Rev Hematol. 2016; 9:1139-1149.

9. Van Cott EM, Khor B, Zehnder JL. Factor V Leiden. Am J Hematol. 2016; 91:46-49.

10. Qi X, Ren W, De Stefano V, Fan D. Associations of coagulation factor V Leiden and prothrombin G20210A mutations with Budd-Chiari syndrome and portal vein thrombosis: a systematic review and meta-analysis. Clin Gastroenterol Hepatol. 2014; 12:1801-1812.e1807.

11. Yioti GG, Panagiotou OA, Vartholomatos GA, Kolaitis NI, Pappa CN, Evangelou E, Stefaniotou MI. Genetic polymorphisms associated with retinal vein occlusion: a Greek case-control study and meta-analysis. Ophthalmic Genet. 2013; 34:130-139.

12. Adamczuk YP, Iglesias Varela ML, Martinuzzo ME, Cerrato GS, Forastiero RR. Central retinal vein occlusion and thrombophilia risk factors. Blood Coagul Fibrinolysis. 2002; 13:623-626.

13. Albisinni R, Coppola A, Loffredo M, Cerbone AM, Di Minno G, Greco GM. Retinal vein occlusion and inherited conditions predisposing to thrombophilia. Thromb Haemost. 1998; 80:702-703.
14. Arsene S, Delahousse B, Regina S, Le Lez ML, Pisella PJ, Gruel Y. Increased prevalence of factor V Leiden in patients with retinal vein occlusion and under 60 years of age. Thromb Haemost. 2005; 94:101-106.

15. Batioglu F, Atmaca LS, Karabulut HG, Beyza Sayin D. Factor V Leiden and prothrombin gene G20210A mutations in ocular Behcet disease. Acta Ophthalmol Scand. 2003; 81:283-285.

16. Biancardi AL, Gadelha T, Borges WI, Vieira de Moraes H $\mathrm{Jr}$, Spector N. Thrombophilic mutations and risk of retinal vein occlusion. Arq Bras Oftalmol. 2007; 70:971-974.

17. Bombeli T, Basic A, Fehr J. Prevalence of hereditary thrombophilia in patients with thrombosis in different venous systems. Am J Hematol. 2002; 70:126-132.

18. Ciardella AP, Yannuzzi LA, Freund KB, DiMichele D, Nejat M, De Rosa JT, Daly JR, Sisco L. Factor V Leiden, activated protein $\mathrm{C}$ resistance, and retinal vein occlusion. Retina. 1998; 18:308-315.

19. Cruciani F, Moramarco A, Curto T, Labate A, Recupero V, Conti L, Gandolfo GM, Balacco Gabrieli C. MTHFR C677T mutation, factor II G20210A mutation and factor V Leiden as risks factor for youth retinal vein occlusion. Clin Ter. 2003; 154:299-303.

20. De Polo L, Maltese PE, Rigoni E, Bertelli M, Cecchin S, Staurenghi G, Stoppa G. Genetic polymorphisms and retinal vein occlusion in an Italian population. Genet Mol Res. 2015; 14:13337-13341.

21. Delahousse B, Arsene S, Piquemal R, Iochmann S, Le Lez ML, Pouplard C, Gruel Y. The 20210A allele of the prothrombin gene is not a risk factor for retinal vein occlusion. Blood Coagul Fibrinolysis. 1998; 9:447-448.

22. Demirci FY, Guney DB, Akarcay K, Kir N, Ozbek U, Sirma S, Unaltuna N, Ongor E. Prevalence of factor V Leiden in patients with retinal vein occlusion. Acta Ophthalmol Scand. 1999; 77:631-633.

23. Di Capua M, Coppola A, Albisinni R, Tufano A, Guida A, Di Minno MN, Cirillo F, Loffredo M, Cerbone AM. Cardiovascular risk factors and outcome in patients with retinal vein occlusion. J Thromb Thrombolysis. 2010; 30:16-22.

24. Dixon SG, Bruce CT, Glueck CJ, Sisk RA, Hutchins RK, Jetty V, Wang P. Retinal vascular occlusion: a window to diagnosis of familial and acquired thrombophilia and hypofibrinolysis, with important ramifications for pregnancy outcomes. Clin Ophthalmol. 2016; 10:1479-1486.

25. Dodson PM, Haynes J, Starczynski J, Farmer J, Shigdar S, Fegan G, Johnson RJ, Fegan C. The platelet glycoprotein Ia/ IIa gene polymorphism C807T/G873A: a novel risk factor for retinal vein occlusion. Eye (Lond). 2003; 17:772-777.

26. Faude S, Faude F, Siegemund A, Wiedemann P. [Activated protein $\mathrm{C}$ resistance in patients with central retinal vein occlusion in comparison to patients with a history of deepvein thrombosis and a healthy control group]. [Article in German]. Ophthalmologe. 1999; 96:594-9. 
27. Glueck CJ, Bell H, Vadlamani L, Gupta A, Fontaine RN, Wang P, Stroop D, Gruppo R. Heritable thrombophilia and hypofibrinolysis. Possible causes of retinal vein occlusion. Arch Ophthalmol. 1999; 117:43-49.

28. Glueck CJ, Wang P, Bell H, Rangaraj V, Goldenberg N. Associations of thrombophilia, hypofibrinolysis, and retinal vein occlusion. Clin Appl Thromb Hemost. 2005; 11:375-389.

29. Gori AM, Marcucci R, Fatini C, Gensini F, Sticchi E, Sodi A, Cappelli S, Menchini U, Gensini GF, Abbate R, Prisco D. Impaired fibrinolysis in retinal vein occlusion: a role for genetic determinants of PAI-1 levels. Thromb Haemost. 2004; 92:54-60.

30. Graham SL, Goldberg I, Murray B, Beaumont P, Chong $\mathrm{BH}$. Activated protein $\mathrm{C}$ resistance-low incidence in glaucomatous optic disc haemorrhage and central retinal vein occlusion. Aust N Z J Ophthalmol. 1996; 24:199-205.

31. Greiner K, Peetz D, Winkgen A, Prellwitz W, Pfeiffer N, Hafner G. Genetic thrombophilia in patients with retinal vascular occlusion. Int Ophthalmol. 1999; 23:155-160.

32. Horoz H, Erbil HH, Sen V, Duru E, Aral H. Activated protein $\mathrm{C}$ resistance and lipoprotein (a) in young adults with branch retinal vein occlusion. Ann Ophthalmol. 2005; 37:267-271.

33. Johnson TM, El-Defrawy S, Hodge WG, Leonard BC, Kertes PJ, Taylor SAM, Lillicrap DP. Prevalence of factor V Leiden and activated protein $\mathrm{C}$ resistance in central retinal vein occlusion. Retina. 2001; 21:161-166.

34. Kalayci D, Gurgey A, Guven D, Parlak H, Hasiripi H. Factor V Leiden and prothrombin 20210 A mutations in patients with central and branch retinal vein occlusion. Acta Ophthalmol Scand. 1999; 77:622-624.

35. Karska-Basta I, Kubicka-Trzaska A, Romanowska-Dixon B, Undas A. [Thrombophilia - a risk factor of retinal vein occlusion?]. [Article in Polish]. Klin Oczna. 2013; 115: 29-33.

36. Koylu MT, Kucukevcilioglu M, Erdurman FC, Durukan AH, Sobaci G, Torun D, Tunca Y, Ayyildiz O. Association of retinal vein occlusion, homocysteine, and the thrombophilic mutations in a Turkish population: A case-control study. Ophthalmic Genet. 2017 Jan 13. [Epub ahead of print].

37. Kuhli C, Hattenbach LO, Scharrer I, Koch F, Ohrloff C. High prevalence of resistance to APC in young patients with retinal vein occlusion. Graefes Arch Clin Exp Ophthalmol. 2002; 240:163-168.

38. Kuhli-Hattenbach C, Hellstern P, Nagler DK, Kohnen T, Hattenbach LO. Prothrombin polymorphism A19911G, factor V HR2 haplotype A4070G, and plasminogen activator-inhibitor-1 polymorphism $4 \mathrm{G} / 5 \mathrm{G}$ and the risk of retinal vein occlusion. Ophthalmic Genet. 2017 Jan 13. [Epub ahead of print].

39. Lahey JM, Tunc M, Kearney J, Modlinski B, Koo H, Johnson RN, Tanaka S. Laboratory evaluation of hypercoagulable states in patients with central retinal vein occlusion who are less than 56 years of age. Ophthalmology. 2002; 109:126-131.
40. Larsson J, Sellman A, Bauer B. Activated protein C resistance in patients with central retinal vein occlusion. $\mathrm{Br}$ J Ophthalmol. 1997; 81:832-834.

41. Marcucci R, Bertini L, Giusti B, Brunelli T, Fedi S, Cellai AP, Poli D, Pepe G, Abbate R, Prisco D. Thrombophilic risk factors in patients with central retinal vein occlusion. Thromb Haemost. 2001; 86:772-776.

42. Marcucci R, Giusti B, Betti I, Evangelisti L, Fedi S, Sodi A, Cappelli S, Menchini U, Abbate R, Prisco D. Genetic determinants of fasting and post-methionine hyperhomocysteinemia in patients with retinal vein occlusion. Thromb Res. 2003; 110:7-12.

43. Mrad M, Fekih-Mrissa N, Wathek C, Rannen R, Gabsi $\mathrm{S}$, Gritli N. Thrombophilic risk factors in different types of retinal vein occlusion in Tunisian patients. J Stroke Cerebrovasc Dis. 2014; 23:1592-1598.

44. Rehak M, Krcova V, Slavik L, Fric E, Langova K, Ulehlova J, Rehak J. The role of thrombophilia in patients with retinal vein occlusion and no systemic risk factors. Can J Ophthalmol. 2010; 45:171-175.

45. Risse F, Frank RD, Weinberger AW. Thrombophilia in patients with retinal vein occlusion: a retrospective analysis. Ophthalmologica. 2014; 232:46-52.

46. Salomon O, Moisseiev J, Rosenberg N, Vidne O, Yassur I, Zivelin A, Treister G, Steinberg DM, Seligsohn U. Analysis of genetic polymorphisms related to thrombosis and other risk factors in patients with retinal vein occlusion. Blood Coagul Fibrinolysis. 1998; 9:617-622.

47. Aras S, Yilmaz G, Alpas I, Baltaci V, Tayanc E, Aydin P. Retinal vein occlusion and factor $\mathrm{V}$ Leiden and prothrombin $20210 \mathrm{G}$ :A mutations. Eur J Ophthalmol. 2001; 11:351-355.

48. Janssen MC, den Heijer M, Cruysberg JR, Wollersheim H, Bredie SJ. Retinal vein occlusion: a form of venous thrombosis or a complication of atherosclerosis? A metaanalysis of thrombophilic factors. Thromb Haemost. 2005; 93:1021-1026.

49. Gumus K, Kadayifcilar S, Eldem B, Saracbasi O, Ozcebe O, Dundar S, Kirazli S. Is elevated level of soluble endothelial protein $\mathrm{C}$ receptor a new risk factor for retinal vein occlusion? Clin Experiment Ophthalmol. 2006; 34:305-311.

50. Larsson J, Hillarp A. The prothrombin gene G20210A mutation and the platelet glycoprotein IIIa polymorphism P1A2 in patients with central retinal vein occlusion. Thromb Res. 1999; 96:323-327.

51. Linna T, Ylikorkala A, Kontula K, Puska P, Tervo T. Prevalence of factor V Leiden in young adults with retinal vein occlusion. Thromb Haemost. 1997; 77:214-216.

52. Rehak M, Rehak J, Muller M, Faude S, Faude F, Siegemund A, Krcova V, Slavik L, Hasenclever D, Scholz M, Wiedemann P. The prevalence of activated protein C (APC) resistance and factor $\mathrm{V}$ Leiden is significantly higher in patients with retinal vein occlusion without general risk factors. Case-control study and meta-analysis. Thromb Haemost. 2008; 99:925-929. 
53. Weger M, Renner W, Steinbrugger I, Cichocki L, Temmel W, Stanger O, El-Shabrawi Y, Lechner H, Schmut O, Haas A. Role of thrombophilic gene polymorphisms in branch retinal vein occlusion. Ophthalmology. 2005; 112:1910-1915.

54. Margaglione M, Brancaccio V, Ciampa A, Papa ML, Grandone E, Di Minno G. Inherited thrombophilic risk factors in a large cohort of individuals referred to Italian thrombophilia centers: distinct roles in different clinical settings. Haematologica. 2001; 86:634-639.
55. Govetto A, Dominguez R, Rojas L, Pereiro M, Lorente R. Bilateral and simultaneous central retinal vein occlusion in a patient with obstructive sleep apnea syndrome. Case Rep Ophthalmol. 2014; 5:150-156.

56. Moher D, Liberati A, Tetzlaff J, Altman DG. Preferred reporting items for systematic reviews and meta-analyses: the PRISMA statement. PLoS Med. 2009; 6:e1000097. 